\section{CHEMORESISTANCE CAN LIMIT THE SUCCESS OF RADICAL SURGERY FOLLOWED BY EARLY POSTOPERATIVE INTRAPERITONEAL CHEMOTHERAPY IN GASTRIC CARCINOMA}

\section{To the Editor:}

We read with great interest the excellent review and rationale on gastric carcinoma management by Drs. González and Sugarbaker. They also offer a strategy to avoid locoregional and peritoneal recurrence that occurs very frequently in advanced stages following resection and has a fatal prognosis. The extended lymph node clearance followed by intraperitoneal chemotherapy is advocated by some Asian surgeons but it is rarely performed in Western countries, probably due to the traditional pessimistic point of view of Western surgeons when treating this neoplasia. This feeling has been reinforced by the prospective European trials failing to demonstrate an improvement in the survival rates of patients with advanced disease on whom extended lymphadenectomies were performed $^{1-3}$. In our opinion, these trials show that radical surgery alone is an insufficient treatment for most of these patients, and we agree with the authors that new strategies combining regional or systemic therapy with extended lymphadenectomies must be carried out to prevent recurrence. However, the strategy proposed needs specifically trained surgeons and intraperitoneal chemotherapy is not a simple procedure or available in the majority of our hospitals. For that reason the author's approach must clearly demonstrate benefits in survival terms before being incorporated into our protocols.

In addition, we would like to point our that although early intraoperative chemotherapy reaches high concentrations of drugs in peritoneal surfaces, the chemosensitivity of gastric cancer cells to be killed has not been taken into account. We believe the reason that iv drug combinations have not improved survival of these patients must also be found in the complex pattern of chemoresistance shown by this neoplasia ${ }^{4-8}$. For instance, anthracyclines commonly included in chemotherapy regimens against gastric carcinoma during the last decade are being abandoned. The frequent expression of P-glycoprotein, MRP and p53 mutations shown by this neoplasia impair the effectiveness of these drugs and would support this attitude. We suggest that the main factors in chemoresistance that can impair the effectiveness of the drugs employed should be tested before administration. If this is not done, the study's potentially poor results could be attributed to the procedure which in fact is a problem of chemoresistance.

Rev Oncología 2000; 2: 322.

Recibido el 26-5-2000.

Aceptado para su publicación el 21-6-2000.

\section{Bibliografía}

1. Siewert JR, Bötcher K, Stein HJ, Roder JD and the German Gastric Carcinoma Study Group. Relevant prognostic factors in gastric cancer. Ten-year results of the German Gastric Cancer Study. Ann Surg 1998; 228: 449-461.

2. Bonenkamp JJ, Hermans J, Sasako M, Van de Velde CJH, for the Dutch Gastric Cancer Group. Extended lymph-node dissection for gastric cancer. N Engl J Med 1999; 340: 908-914.

3. Cuschieri A, Weeden S, Fielding J, et al. Patient survival after D1 and D2 resections for gastric cancer: long term results of the MRC randomized surgical trial. Br J Cancer 1999; 79: 1.522-1.530.

4. Endo K, Maehara Y, Kusumoto T, Ichiyoshi Y, Kuwano M, Sugimachi K. Expression of multidrug-resistance-associated protein (MRP) and chemosensitivity in human gastric cancer. Int J Cancer 1996; 68: 372-376.

5. Lacueva FJ, Calpena R, Medrano J, et al. Changes in P-glycoprotein expression in gastric carcinoma with respect to distant gastric mucosa may be influenced by p53. Cancer 2000; 89 (1): 21-28.

6. Lowe SW, Ruley HE, Jacks T, Housman DE. p53-dependent apoptosis modulates the cytotoxicity of anticancer agents. Cell 1993; 74: 957-967.

7. Johnston PG, Lenz HJ, Leichman CG, et al. Thymidylate synthase gene and protein expression correlate and are associated with response to 5-fluoracil in human colorectal and gastric tumors. Cancer Res 1995; 55: 1.407-1.412.

8. Aebi S, Fink D, Gordon R, et al. Resistance to cytotoxic drugs in DNA mismatch repair-deficient cells. Clin Cancer Res 1997; 3: 1.763-1.767.

\section{F. Javier Lacueva, Rafael Calpena, Justo Medrano and Israel Oliver Department of Pathology and Surgery. School of Medicine. Miguel Hernández University. Alicante.}

\section{CHEMORESISTANCE CAN LIMIT \\ THE SUCCESS OF RADICAL SURGERY \\ FOLLOWED BY EARLY POSTOPERATIVE \\ INTRAPERITONEAL CHEMOTHERAPY \\ IN GASTRIC CARCINOMA (REPLY)}

\section{To the Editor:}

We appreciate the comments by Dr. Lacueva and colleagues about our article on the comprehensive management of gastric cancer.

We share with other authors ${ }^{1}$ the opinion that the pessimistic point of view of Western surgeons regarding extended resections for gastric cancer has not been established at the present time. Controversy regarding the extent of lymphadenectomy has not been settled yet, not even after the results of the European randomized trials have been reported ${ }^{2,3}$. There are rational arguments both for and against extensive lymphadenectomy that prevent valid conclusions. Surgical skill and expertise in cancer surgery ${ }^{4}$ has been shown to affect outcome. However, in the Dutch trial, the

Rev Oncología 2000; 2: 322-324.

Recibido el 15-9-2000.

Aceptado para su publicación el 20-9-2000. 